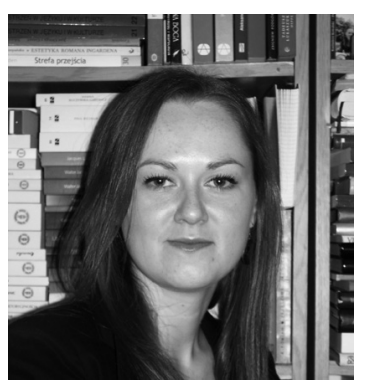

Małgorzata Czapiga

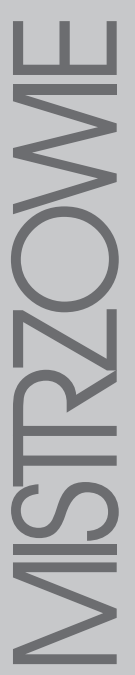

Małgorzata Czapiga - absolwentka polonistyki Uniwersytetu Jagiellońskiego, doktor nauk humanistycznych w zakresie etnologii; aktualnie doktorantka na Wydziale Zarządzania i Komunikacji Społecznej UJ. Interesuje się szczególnie historią kultury, historią wyobrażeń i symboli, oral history, teatrem awangardowym, radiem i audiosferą. Publikowała w "Kontekstach”, „Literaturze Ludowej”, „Znaczeniach”, „Kulturze Współczesnej" i in. Autorka jest ostatnim doktorem wypromowanym przez Prof. Piotra Kowalskiego. 


\section{Nieuporządkowana biblioteka bez dzieł zebranych Wspomnienie o Profesorze Piotrze Kowalskim}

„[... ] im więcej pamiętamy, tym bliżej może jesteśmy umierania”.

$\mathbf{R}$

ubryka „Mistrzowie” wydaje się bardzo adekwatna do umieszczenia w niej wspomnienia o Piotrze Kowalskim, jak i - paradoksalnie - zupełnie nieodpowiednia. Spoza słowa „mistrz” wyziera posągowość, ustabilizowany status koturnowości, mierzony wyższością, godnością czy zwierzchnictwem. „Mistrz” stabilizuje obraz niedoścignionej doskonałości, ale potrąca równocześnie struny oddalenia i pewnej nienaturalności. Szacunek i podziw zlewa się $\mathrm{w}$ amalgamat $\mathrm{z}$ oddzieleniem i nierealnością kontaktu. Słowa zawodzą przy odtwarzaniu rzeczywistości. Z jednej strony Profesor był i pozostaje niepodważalnym autorytetem, wytyczną działań i przedsięwzięć swoich uczniów oraz współpracowników, z drugiej jednak każdy, kto się z nim zetknął, poznawał Człowieka, który nie stwarzał dystansu, nie wynosił się ponad swojego rozmówcę, pozwalał czuć się równoprawnym partnerem. Jego wiedza i erudycja onieśmielały, a otwartość i bezpretensjonalność dodawały odwagi. Po prostu Mistrz. Po prostu Człowiek.

Pamięć, podobnie jak sztuka, ma skłonność do selekcji i zamiłowanie do szczegółów. Choć ta uwaga odnośnie sztuki (szczególnie prozy), może się wydać niezasłużonym komplementem, dla pamięci powinna być obraźliwa. Obraza jest uzasadniona, gdyż pamięć zachowuje właśnie detale, a nie cały obraz, czy też, jak kto woli, kluczowe sceny, a nie całe przedstawienie. Przekonanie, że w jakiś sposób pamiętamy całość ze wszystkimi szczegółami - ta pewność, dzięki której ludzie kontynuują życie - jest bezpodstawne. Pamięć przypomina najbardziej nieuporządkowaną bibliotekę bez dzieł zebranych jakiegokolwiek autora ${ }^{2}$.

J. Brodski, Mniej niż ktoś, tłum. K. Tarnowska, A. Konarek, [w:] idem, Mniej niż ktoś. Eseje, Kraków 2006, s. 29

2 Idem, W półtora pokoju, tłum. A. Husarska, [w:] idem, Dyptyk petersburski, czyli przewodnik po przemianowanym mieście, Warszawa 2003, s. 65. 
W żaden sposób nie uda się już stworzyć całościowego obrazu człowieka, który odszedł. Nie podoła temu zadaniu ktokolwiek w pojedynkę, nie złoży się go ani z luźnych, ani nad wyraz rzetelnych narracji, gromadzonych jak pojedyncze okruchy świadectw. Każda próba nie będzie opowieścią o faktach, ale impresją dotyczącą tego, co odczuwało się w obliczu tych faktów. A skoro pamięć jest nieuporządkowaną biblioteką wyselekcjonowanych szczegółów, to sam proces wspominania musi pozostać nielinearny i w jakiś sposób chaotyczny.

Piotra Kowalskiego poznałam podczas zajęć w Instytucie Etnologii i Antropologii Kulturowej UJ. Już wtedy był w bezustannej podróży - przyjeżdżał do Krakowa na czwartkowo-piątkowe wykłady. Ludowa wizja świata, którą opisywał, zapadający zmierzch popołudniowej pory i Jego nieśpieszna, barwna narracja stwarzały niezwykły klimat zajęć. Słuchaliśmy Go, chłonąc kolejne opowieści, bo właściwie trudno byłoby mówić o „wykładach” w klasycznym rozumieniu. Umiał opowiadać, jak mało kto. Zbędne stawały się prezentacje, zdjęcia, ilustracje, filmy - wystarczyło, że mówil, a jeśli nawiązywał do konkretnych wytworów kultury, to zwabieni urokiem Jego narracji, i tak po nie sięgaliśmy. Później przekonaliśmy się, że nieważne, czy były to zajęcia poświęcone folklorowi, antropologii podróży, czy kulturze popularnej (żeby wymienić choć kilka planów z ogromnego zakresu zainteresowań Piotra Kowalskiego), wciąż towarzyszył Mu gawędziarski, a równocześnie niezwykle erudycyjny sposób prowadzenia zajęć. Mówił z przekonaniem, a w ten sposób przekonywał, bo żył tematami, którymi się zajmował. Podczas jednego z konwersatoriów rozważaliśmy kwestie tradycyjnych podań wierzeniowych oraz narracji wierzeniowych kultury współczesnej. Profesor Kowalski nawiązał do historii, które krążyły w obiegu oralnym podczas wielkiej powodzi z 1997 roku, a dotyczyły rzekomego utonięcia nosorożca pochodzącego z opolskiego zoo. Próbując nam wytłumaczyć mechanizmy oralnych przekazów pojawiających się szczególnie w chwilach kryzysu, ich formuliczności, wariantywności itd., posłużył się wspomnianym przykładem, tyle że ciągle mówił o „jednorożcu”! Zdziwieni coraz bardziej, słuchaliśmy uważnie, żeby ostatecznie zacząć wymieniać porozumiewawcze uśmiechy. Zauważył to i niczym nieskonfundowany, odrzekł: „Nie rozumiem, skąd ten śmiech. Naprawdę był tam jednorożec, ale z gatunku małych jednorożców!” Śmiechu nie dało się dłużej wstrzymywać i wytłumaczyliśmy powody tych salw. Wtedy akurat Profesor pisał o symbolice i wyobrażeniu jednorożca w kulturach świata. Pochłonięty zajęciami, konferował, ale podświadomie wracał do najbardziej zajmującego Go wtedy wątku...

Zajęcia się kończyły, ale nadal trwały. Naturalna płynność nadana tym spotkaniom przenosiła nas na dziedziniec instytutu. Rytuałem stały się dyskusje „przy papierosie”, które odbywaliśmy po wykładach. Kameralne wewnętrzne podwórko krakowskiej etnologii, grupa studentów i On - Mistrz. Niespiesznie prowadzone rozmowy snuły się najczęściej wokół tematu, który akurat wywołany był na zajęciach, zadawaliśmy pytania, a czasem nawet śmielej - podawaliśmy jakieś kwestie w wątpliwość. Nigdy nie spotkaliśmy się z brakiem zrozumienia, autorytarnym tonem czy apodyktyczną opinią. Wiedzieliśmy, że Piotr Kowalski miał swoje zdanie, swoje preferencje i swoje oceny, o których nie bał się mówić otwarcie i odważnie, ale pozwalał nam na to samo. Nie chodziło o wzajemne przekonywanie do naszych racji, ale o dyskusję, w której klarowały się sądy i opinie. Uczył nas myśleć samodzielnie, stawiać sobie problemy i krytycznie je prześwietlać. Dzieliliśmy się nowymi 


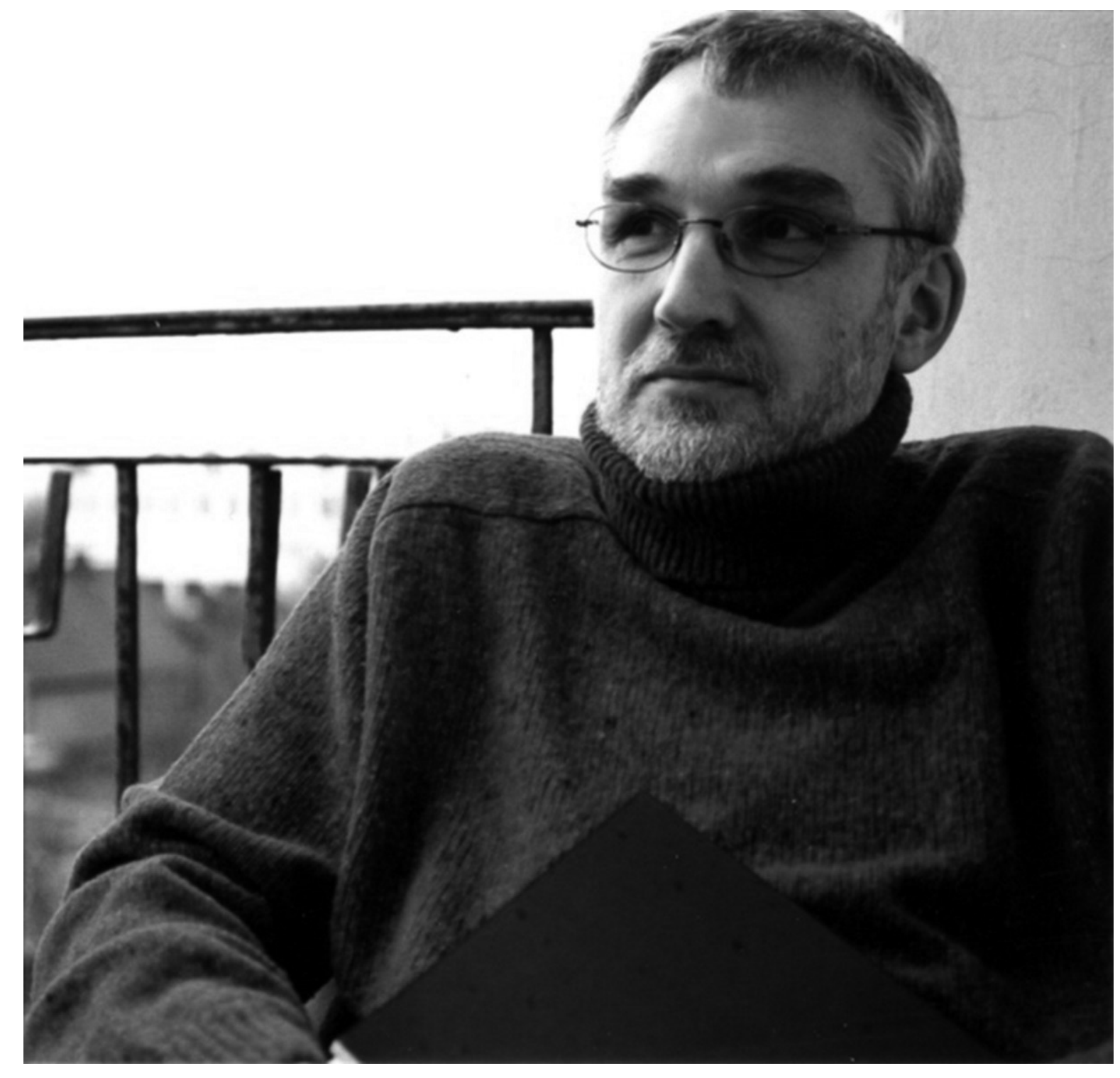

Profesor Piotr Kowalski

(1952-2011).

Fot. Magdalena Sztandara 
pomysłami i doświadczeniami naukowymi. Tylko w jednej kwestii pozostawaliśmy na zawsze bez szans. W kwestii książek.

Nie było właściwie takich książek, o których by nie słyszał, a większość po prostu miał. Co tydzień wykonywał tzw. obchód po krakowskich księgarniach, gdzie znano już Jego upodobania i zainteresowania. Ale książki kupował wszędzie - podczas wyjazdów służbowych i prywatnych, a w ostatnim czasie również przez Internet. Pochłaniał niewyobrażalne dla nas ilości tych książek, czytał i zapamiętywał. Narzekał, że zarasta piętrzącymi się stosami tomów, na które brak już miejsca na półkach, ale kupował kolejne i kolejne. Nie fetyszyzował ich jednak - nie chodziło o posiadanie dla samego posiadania. Często pożyczał je nam jako inspiracje czy pomoc do konkretnych rozważań, nierzadko po przeczytaniu - po prostu darował. Część z nich potrzebna Mu była do pracy, inne kupował ze względu na przyszłe plany pisarskie, ale przede wszystkim czytał, żeby wiedzieć, bo chciał wiedzieć i rozumieć - świat, ludzi i siebie. Wielokrotnie powtarzał: „Kiedy pracuję, to czytam. A kiedy odpoczywam ... to czytam!”. Nie było cezury między pracą a życiem, obowiązkami a przyjemnościami, zlewały się w jedno i przeplatały nieustannie. $Z$ tego też brała swój początek robiąca wrażenie liczba publikacji Piotra Kowalskiego, bo nie pisał z przymusu, dla stopni, sławy czy pieniędzy. Pisał, bo to było od zawsze Jego rudymentarne doświadczanie rzeczywistości, które wynikało z niezwykle wyczulonej obserwacji, umiejętności analizy tego, co wokól, oraz lekkości w uchwyceniu analogii między, w pierwszej chwili wydawałoby się, zupełnie odległymi czasowo, wyobrażeniowo, kulturowo mechanizmami czy procesami.

I dlatego nie funkcjonowały w Jego odczuciu „złe” tematy, niewarte zachodu, niezbyt wartościowe, żeby się nimi zająć. W wielu naszych seminaryjnych czy prywatnych rozmowach wspominaliśmy Profesorowi o rzeczach, które nas dziwią, intrygują, bawią, z jakichś powodów zajmują, a On często pytał: „To dlaczego o tym nie piszesz?”. Banalny zrazu temat, przedyskutowany, odnaleziony w nowych kontekstach, stawał się zalążkiem, który mieliśmy drążyć aż do granic możliwości. Jego metoda okazywała się naszą metodą. Nie wybieraliśmy treści z listy proponowanych, nie podejmowaliśmy wątków modnych, ale pisaliśmy o tym, co nas w najgłębszym wymiarze dotyczyło; bardziej lub mniej udolnie, ale mieliśmy swoje tematy.

Nie miało tak naprawdę znaczenia, czy było się kilkuletnim studentem, wieloletnim współpracownikiem czy nowo poznanym na konferencji rozmówcą, Profesor posiadał dużą zdolność zjednywania sobie ludzi. Jego sposób bycia najpierw ujawniał Człowieka, w drugiej kolejności Mistrza. Otwartość i łatwość kontaktów, przy równocześnie ogromnej wiedzy i kompetencjach, sprawiały, że w wielu ośrodkach uniwersyteckim mial „małe grona swoich wyznawców". Jak wiele osób Go ceniło i jak wielu uważało się za Jego uczniów, uświadomiliśmy sobie z niezwykłą wyrazistością w dramatycznych chwilach po odejściu Profesora.

Ludzie-znaki na mapie Jego podróży nie wzięli się znikąd. Całemu życiu Piotra Kowalskiego towarzyszył jakiś nieprzemożony pęd do wiecznego bycia w ruchu. Z Brzegu, gdzie się urodził, przeniósł się z rodzicami do Opola, żeby później studiować we Wrocławiu, pracować $w$ innych miastach (na uniwersytetach i w ramach PKA) i osiąść na dobre znów we Wrocławiu. Zatoczył koło, żeby odnaleźć swoje miejsce. Dotarł tutaj, by nie iść już więcej. Warto było wyjeżdżać i dać się latami rzucać wiatrom niepoznanych losów tylko po to, żeby przekonać się, że miejscem dojścia jest punkt wyjścia? Na pewno powiedziałby, że warto. Mimo wszystko. Bo co, gdyby nie było tego wszystkiego, co „po drodze”? Wielokrot- 
nie w rozmowach wracał do swojego drugiego, obok Konstantego Ildefonsa Gałczyńskiego, ulubionego poety - Konstandinosa Kawafisa. Gdzieś wybrzmiewały Mu słowa jednego z wierszy:

Jeśli wyruszasz w podróż do Itaki, pragnij tego, by długie było wędrowanie, pełne przygód, pełne doświadczeń.

Lajstrygonów, Cyklopów, gniewnego Posejdona nie obawiaj się. Nic takiego na twojej drodze nie stanie, jeśli myślą trwasz na wyżynach, jeśli tylko wyborne uczucia dotykają twego ducha i ciała. Ani Lajstrygonów, ani Cyklopów, ani okrutnego Posejdona nie spotkasz, jeżeli ich nie niesiesz w swojej duszy, jeśli własna twa dusza nie wznieci ich przed tobą.

Pragnij tego, by wędrowanie było długie: żebyś miał wiele takich poranków lata, kiedy, z jaką uciechą, z jakim rozradowaniem, będziesz podplywał do portów, nigdy przedtem nie widzianych; żebyś się zatrzymywał w handlowych stacjach Fenicjan i kupowal tam piękne rzeczy, masę perłową i koral, bursztyn i heban, i najróżniejsze, wyszukane olejki ile ci się uda zmysłowych wonności znaleźć. Trzeba też, byś egipskich miast odwiedził wiele, aby uczyć się i jeszcze się uczyć - od tych, co wiedzą. Przez cały ten czas pamiętaj o Itace.

Przybycie do niej - twoim przeznaczeniem. Ale bynajmniej nie śpiesz się w podróży. Lepiej, by trwała ona wiele lat, abyś stary już był, gdy dobijesz do tej wyspy, bogaty we wszystko, co zyskałeś po drodze, nie oczekują wcale, by ci dała bogactwo Itaka. Itaka dała ci tę piękną podróż.

Bez Itaki nie wyruszyłbyś w drogę.

Niczego więcej już ci dać nie może.

A jeśli ją znajdujesz ubogą, Itaka cię nie oszukała.

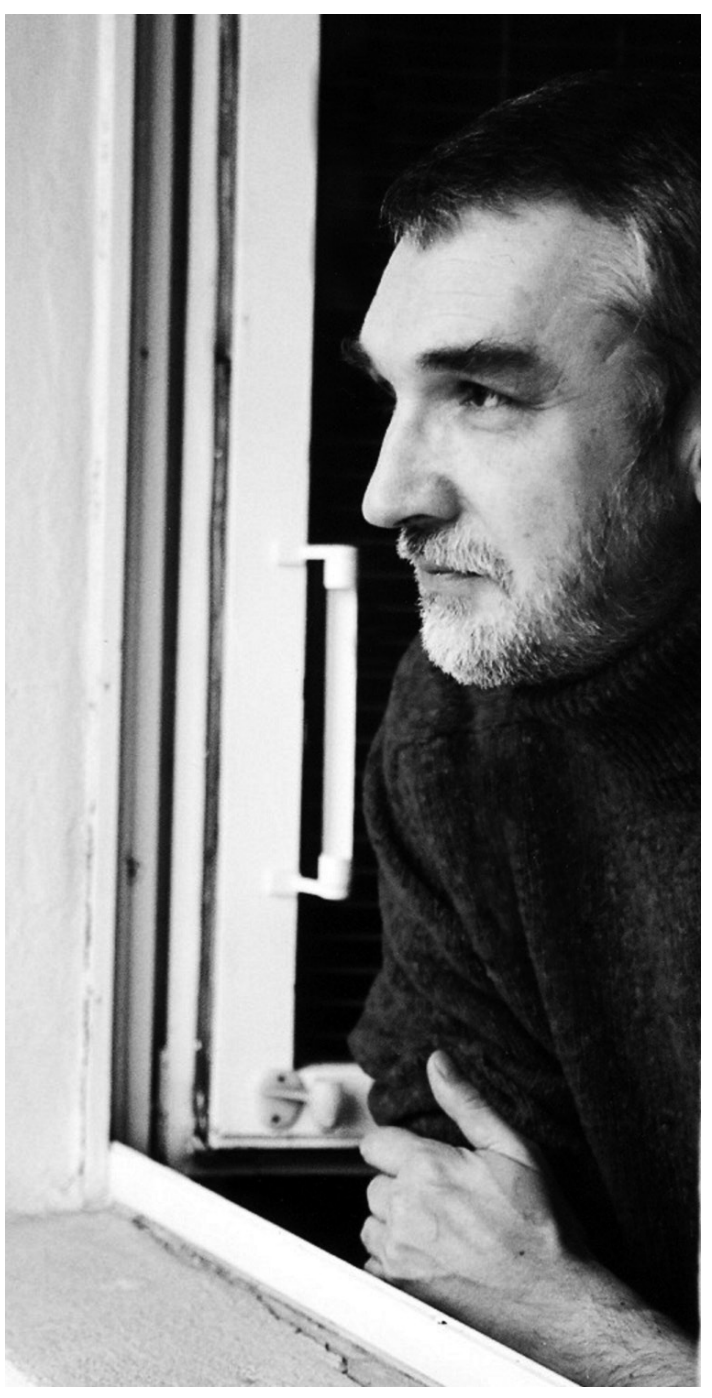

Fot. Magdalena Sztandara Gdy się stałeś tak mądry, po tylu doświadczeniach, już zrozumiałeś, co znaczą Itaki³

Jego podróż była za krótka.

${ }^{3}$ K. Kawafis, Itaka, [w:] idem, Wiersze zebrane, tłum. Z. Kubiak, Warszawa 1995, s. 40-41. Wiersz ten otwiera książkę Piotra Kowalskiego Odyseje nasze byle jakie. Droga, przestrzeń i podróżowanie w kulturze współczesnej. 